\title{
The Architectural Experience and Configuring the Narrative Spaces in Hikmet's Poetry
}

\author{
Efe Duyan
}

Department of Architecture, Mimar Sinan Fine Arts University, Turkey

Received August 8, 2020; Revised September 7, 2020; Accepted October 19, 2020

\section{Cite This Paper in the following Citation Styles}

(a): [1] Efe Duyan, "The Architectural Experience and Configuring the Narrative Spaces in Hikmet's Poetry," Linguistics and Literature Studies, Vol. 9, No. 1, pp. 1 - 11, 2021. DOI: 10.13189/lls.2021.090101.

(b): Efe Duyan (2021). The Architectural Experience and Configuring the Narrative Spaces in Hikmet's Poetry. Linguistics and Literature Studies, 9(1), 1 - 11. DOI: 10.13189/lls.2021.090101.

Copyright $\bigcirc 2021$ by authors, all rights reserved. Authors agree that this article remains permanently open access under the terms of the Creative Commons Attribution License 4.0 International License

\begin{abstract}
This paper aims to analyze Turkish modernist poet Nâzım Hikmet's architectural spaces in his poetry from the perspective of Paul Ricoeur's theory of architecture and literature to unfold their artistic impact. As an interdisciplinary field, the narratology of space is directly linked to architecture and literature mainly dealing with the described spaces in fiction. Phenomenology and cognitive research, on the other hand, provides a background for the emotional experience of space. Paul Ricoeur's parallelism of architecture and literature rooted in phenomenology will be interpreted from the perspective of narratology of space to provide the main methodology of the research. Paul Ricoeur's theory not only offers a temporal perspective of the need, design, and experience but also provides an interchangeable terminology for narrative spaces. Taking his configuration concept into account, the modernist Turkish poet Nâzım Hikmet's narrative spaces will be analyzed. Ricoeur's theory presents a fitting methodology due to the socio-political discourse and the communicability of Hikmet's poetry. His narrative spaces in different periods will be interpreted according to their emphasis on certain spatial aspects, namely, the emplotment, intelligibility, and context. It will be demonstrated how the spatial qualities of Hikmet's spaces generate corresponding artistic effects. In conclusion, it will be claimed that Hikmet's narrative architecture creates an artistic impact to be experienced by reproducing the main idea, acting as a separate symbol, or shifting the poem's context. The conclusions will also suggest a viewpoint of how narrative qualities may inspire architectural design due to its configurative artistic impact.
\end{abstract}

Keywords Narratology of Space, Poetry, Architecture,
Nâzım Hikmet, Paul Ricoeur

\section{Introduction}

Nâzım Hikmet was the first explicitly modernist poet in the young Turkish republic. Years in the Soviet Union as a student during the 1920s not only shaped Hikmet's understanding of the world as a political activist but also molded him into a fine avant-garde poet. After his return in 1928, he shocked the intellectual community utterly with his experimental texts and self-confident attitude. He was exceedingly political while using a manufactured Futurist language. His use of the two-dimensionality of the text and his abstract spaces were strikingly contributing to his political agenda.

When global political waves of nationalism hit Turkey in the 1930s, Hikmet turned towards a more communicative approach. Society's historical and cultural identity came into his view and his language has softened to comprise the personal emotions on a political background. Hikmet himself, however, a well-known, charismatic, and critical writer, became a man, who was too dangerous to speak of freely. His books were banned and he was locked up in a Turkish prison in 1938 when a fake trial condemned him to 28 years. Nâzım Hikmet's poetry after the mid-1930s has become a combination of the lyrical expression of the self and political functionalism. Both inclinations paved the way for an extensive narration with a descriptive edge. His fantasy epics can be considered a period of transition towards historical epics with a dramatic structure. The 
epics and his conversational style has opened up vast amounts of geographical and architectural environments. This period brought out storytelling long poems including Taranta Babu, The Saga of Sheikh Bedreddin, The Epic of Independence War, and his Human Landscapes from My Country saga in the form of as poetic prose.

Hikmet ultimately left Turkey in 1951 to spend the rest of his life in the Soviet Union, where he was welcomed as a cultural attaché. He was traveling frequently except to his hometown, to which he was not allowed to return by any means. It is no surprise that his poetry in this period obtained a special agenda related to places and cities. The emphasis on the spatial images around the idea of homesickness opened up various strategies and resulted in references to real-life places more often than not. Looking at the cities and places, one comes across a variety of them from Havana Libere Hotel to Uzbeki Gardens in Cairo as the landmarks of his complicated situations.

Hikmet's work is mostly analyzed from a political perspective with an emphasis on his understanding of love. However, a reading of Hikmet's work also reveals a rich pile of materials related to real and imagined places, interiors, cityscapes, scenery, and spatial envisioning intertwined with politics and love. The first group of narrative spaces, all written before mid-1930s during his Futurist-Constructivist period, renders the use of architectural environments abstractly and generically. The use of the page as a two-dimensional entity and a deliberately manufactured language emphasize the physicality and the geometric qualities. His work after mid-1930s manifests an extensive use of spaces as the container of the plot. His stylistic shift to a plain language and realistic tone shaped spaces and places as a frame for the narrative while his historical epics and other poems written in prison showcase lively scenes. And lastly, his poems during his exile between his escape in 1951 and his death in 1963 include his travel impressions of a cultural attaché and feature a strong contextual aspect thanks to the real-life places.

An analysis on the poetic effect of spaces can open up new perspectives on our understanding of Hikmet's works but it requires a multidisciplinary effort. First of all, an architectural space, real or imagined, should be conceived as a producer of poetic experience. Secondly, a methodological understanding of written architectural spaces is to be established.

The question of architecture as experience naturally brings up the significance of the observer's view in physical surroundings, which can be brought back to Baumgarten's striking introduction of the term aesthetics in his Meditations on Poetry. It was Baumgarten's efforts bringing together the object of thought and denominating aesthetics itself as sensible cognition. [1] In the 19th century, supported by the developments in biology and psychology, the architectural experience took a somatosensory turn, as Wölflin's groundbreaking thesis illustrated how architectural forms can invoke an emotion [2] Shortly after, the rise of Phenomenology transferred the spatial awareness into the subjects' grasp, both in cognitive and somatosensory ways. Husserl's subject, das Ich-Zentrum, appropriated the space as the perceived space in the outside world, die Ding-welt, as a transcendental act, [3] while Merleau-Ponty portrayed the bodily movement as the production of the ever-changing architectural space in his Phenomenology of Perception [4]. Following the lead of architects and scholars, who put an emphasis embodied experience such as Neutra in his Survival Through Design, Steen Eiler Rasmussen in Experience of Architecture and Norberg-Schulz in Meaning in Architecture, Juhani Pallasma recently defined the atmosphere as a sixth sense as a total perception of the space in close connection with architectural design supported [5] by cognitive neuroscientific breakthroughs [6]. Yet, the perception and body as the founding elements of architectural space got historically little attention from the architectural practice, which rendered the individual experience mostly as irrelevant to the creative process of the design object. Looking at Hikmet's spaces tough, we can observe how a poet can design an imagined spatiality producing emotional and cognitive experiences. The advantage of Hikmet's written architecture is, obviously, that he is designing not only as forms but also in coexistence with the life inside it. Here, the question arises how to jump from the structure of written text to the architectural imagination.

Another school of thought based on 20th linguistics and structuralism has dealt with architecture as a text focusing on its communicative agenda. Roland Barthes exclusively prescribed urban space that is a signifying space and noted that the city can be considered as a form of writing [7]. In his remarkable study on the semiotics of the Column, Umberto Eco states that, in architecture, the communicative aspect predominates over the functional aspect, and precedes it, as any architectural element needs to make itself known before being used [8]. The narrative spaces, like actual spaces, present the environment as an imagined artifact and producer of meaning. The narration of space envisages the space with the actual life inside it whereas the narrative is interwoven with the urban and interior space. Bringing fiction and design together offers a promising way to conceive the daily life entangled in places, and architectural spaces in life fiction and design can be conceived together. All spaces in fiction are part of the narrative composition, and in that regard, they are designed, too, to facilitate not only the character's actions but also for compositional effects. In that regard, Hikmet's spaces present a rich variety of using narrated space in terms of form, content, and context.

The narratology of space, following the lead of Bakhtin's chronotope, which correlates structures of space with concepts of time or with patterns of actions, tries to capture the role of space in narratives as the environment in 
which characters move, act and live. A semantic point of view, put by Juri Lotman in the 1970s focuses on spatial relations as semantic correlates of cultural values [9]. Joseph Frank, in his Idea of Spatial Form, opens up a field, where space is an internal, relational logic of some modernist literary works that organize their form as a regulative idea [10]. Gabriel Zoran, on the other hand, suggests three-dimensional criteria for defining narrative spaces [11] and, more recently, Katrin Dennerlein focused on the space as the surroundings of the characters in a literal sense [12]. In response to the complexity of definitions, Hamon lists several levels of literary spaces under an order the topographical level being the "signified collective actants, such as places, dwellings, and architectural themes, and also of movements, rituals, and proxemics." [13]

Yet the question remains about how the semiotics of architecture can encapsulate the variedness of Nâzım Hikmet's work derived from his own life experiences if the poems are seen as meaning producing structures. It was Paul Riceur who tried to combine the real life, the work of art and the resulting experience in his theories of literature and architecture. Lewis Hahn notes that Paul Ricoeur sketches out his rejection of the structuralist background of the linguistic sign, objectifying abstraction of semiotics, whereby language was reduced to the functioning of a system of signs without any anchor in a subject [14]. His anthropological philosophy focuses on phenomenological descriptions incorporating structuralism as a method of inquiry. His theory of literature thrives by bringing an existentialist idea of living, the composition, and interpretation together. In other words, his understanding of literature connects the outside world, the text, and the reader. Moreover, his analogy in his essay Literature and Architecture [15] between fiction and architecture is crucial in terms of understanding their intersection, the narrative spaces.

Nâzım Hikmet's poetry, be it political or lyrical, heavily relies on real-life instances. Correspondingly, Ricoeur's starting point for his architecture theory is the dwelling in addition to the building and thinking, which create a Heideggerian triptych as noted by Nikolaos-Ion Terzioglu [16]. For Ricoeur, architecture is not only a mental space, capturing the interpretive experience of the locality by living in the space but he also, through an existentialist reflex, brings dwelling into the equation. His main contribution is to create a bridge between dwelling (the given functional program of a building and basic evolutionary needs of human shelter) and thinking (the experience of space): the building itself as a designed object, which constructs another link to Hikmet, as his poetry is always addressed to someone: a lover, an intellectual rival, or the working class.

For Ricoeur, the need for dwelling/the happenings we encountered (prefiguration) and the experience of dwelling/the interpretation of the text (refiguration) are brought together by the constructed building/written text (configuration). Prefiguration, configuration, and refiguration are closely connected as they engender an all-inclusive matrix for architecture, literature and, also, for the narrated spaces. Hikmet, as a Futurist-Constructivist, put an emphasis on the rationalistic compositions of his poems, too. The configuration, then, is the main area of analysis for Hikmet's poems as sources for spatial experience. How, what and in what context his spaces are used will lead us the way his narrative spaces bring the real-life needs and the reader's experience together.

\section{The Intelligibility of Three-Dimensional Symbols}

\subsection{The Space on the Paper}

Hikmet's poetry in the 1920 s put a special attention on form as he used Futuristic techniques of describing movement by sounds and scenes. The free rhyming, rhythm and shape of the poems play an important role in his famous poem, I want to mechanize, which can be read like a typical expression of Hikmet's Futurism. At the turn of the century, the reaction of urban poor classes to mechanization and the subsequent efforts to harmonize aesthetics with mass production were evident and Hikmet's mindset aimed at shocking the reader by uniting the revolutionary ideas with new technologies. His approach to embracing industrialization results in an abstract yet corporeal construction of the self. He matches up the organs with machines to visualize his persona, and the enthusiastic expression of the personal emotions with the mechanical sounds of "track tiki tak" forges the physical surroundings.

"trrrum

trrrum

trrrum

trak tiki tak

I want to be

Mechanized

I will find a solution to this

and I shall only be happy

on the day I fix a turbine to my belly

and a couple of propellers to my tail" $[17]^{1}$

The Weeping Willow, a requiem, is an eye-catching example of the physicality of Hikmet's spaces. It is a lament for a Bolshevik describing a scene from the civil war in the Soviet Union. The poem is full of audial and visual devices creating an extra layer of spatiality. The inner music of the poem, combined with the line structure, creates a striking visual atmosphere. The lines "Sudden /

\footnotetext{
${ }^{1}$ All translations by Blasing and Konuk, unless specified otherwise.
} 
-ly like a bird / shot / in the wing / a wounded horseman tumbled from his horse" create a perceptible surrounding to enforce the spatial image and action. The reading tempo generates the image of someone who pauses and stumbles. This enforcement technique is used throughout the poem, such as in the lines of "Horsemen, horsemen, red riders, / horses wind winged / horses wind wing / horses wind / horses / horse" [18] As the lines get shorter, the font size correspondingly decreases. The "Horsemen horsemen red horsemen" section, repeated a little shorter in each string to recreate the dying moment of the soldier, who was watching the rest of the riders riding away and becoming distant and, thus, smaller. The sequence "life passed like wind-winged horsemen" repeats the movement of cavalry with the repetition of vowels along with the employment of semi-rhymes and the inclusion of rigid consonants with a particular frequency. The organization of sounds and the placement of poetry on the page establish a harsh, fast, unstoppable, harmonious, and almost transcendental momentum. It is a scene full of action in the three-dimensional space appealing to the senses.

Another noticeable scene can be found in the poem Caspian Sea, where a movement of a boat symbolizes the conflict of not only the humankind with nature but also the working classes with the rulers. The up-down movement of the boat provides a spatial momentum, which is emphasized by the configuration of the words. The narrative is spatialized in such a way to convey a supporting message to main idea:

"the boat moves up

moves down

the boat up

the boat down

up

down"

Pupils of the Hungry displays a variety of formal arrangements with the font and line indents to enhance the meaning. Inspired from his experiences while traveling through Baku, Hikmet presents a very realistic scene only to draw it abstract thanks to his manufactured language.

"hungry are lined-up! Not man, not woman, not boy, not girl

skinny weak

crook branches

crooked trees"

The space in those early poems is an extension of the text in a cubo-futuristic way. They contain the spatialization of the narrative, which is supported by sound devices and the visual composition of the page.

\subsection{Physicality as Symbol}

Body and space, presented generically, can easily be linked to a symbolic universe. Talking about his weakness for beautiful women distracting him from his so-called revolutionary duties, his poem Worm in my Body displays an extensive use of bodily images. In The Blue-Eyed Giant, the Miniature, he uses the physicality of woman's body as a simple symbol -the anti-thesis of his passionate life as a revolutionary.

"He was a blue-eyed giant,

He loved a miniature woman.

The woman's dream was of a miniature house

with a garden where honeysuckle grows

in a riot of colours

that sort of house."

Accompanied by a play of colors, The Fire depicts a house with sick people. The skin of patients and the lantern are pale yellow, the night and the road are black, and the house and the snow are white, and, in the ending, the foreheads of the sick people become red because of the scars. The reader is walked through representational images of color. The Volcano symbolizes the action as the anti-thesis of the passivity of interiors, whereas Collossos, exemplifies the poet himself, mighty but with a plaster structure inside, which is doomed to crash if he can't achieve his ambitions soon. While Prehistoria depicts a symbolic far-away to imply the great achievements done by the working classes, the famous poem Optimism conceives the speed of the racing boat as the march towards his political goals. In Wall, he talks about executions carried out in different countries and the wall stands for the tragic ending of revolutionaries. Portable Bedstead portrays an empty room in a very generic way to emblematize a friend's death. The City that lost his Voice depicts a surreal scene of three musicians on an empty street late in the night. This scene symbolizes the political oppression and the silence of the masses through the expressions such as "the asphalt that couldn't be convinced to speak up."

The poems in his first three books offer a similar generic physicality using architectural objects (suspension bridges, houses, rooms, squares, roads), geographical entities (volcanos, mountains, and seas) or the body itself as symbols.

\subsection{Hikmet's Fantastic Epics and Space as the Mirror of the Mood}

His fantasy-crime romance Giaconda and SI-YA-U published in 1929 was the first of his long, story-telling poems. The surrealistic poem is about Da Vinci's Mona Lisa, who falls in love with a Chinese communist, Si-Ya-U, and decides to elope with him. The poem has elements of Louvre interiors, adventurous journeys, Chinoiserie and reflects the massacre of leftists in Shanghai in 1927. Si-Ya-U is Hsiao San (b. 1896) in real life. Hikmet met him in Moscow in 1922 and believed he had been executed in the bloody crackdown on Shanghai radicals, after the Mona Lisa did in fact disappear from the Louvre. They were reunited in Vienna in 1951 and traveled to Peking together. 
Translated into Chinese, this poem was later burned-along with Hsiao's works in the Cultural Revolution.

The opening part is about Gioconda's impressions on the Louvre and how boring it is for her to be "closed". The contrast between the revolutionary hard-working Chinese and the world of paintings of the elite exhibited in Louvre is impossible to miss.

"a museum is fine,

to be a museum piece is terrible!

In this palace that imprisons the past

I am placed under such a heavy sentence

that as the paint on my face cracks out of boredom"

Once the SI Ya U is deported due to political reasons, Mona Lisa escapes and follows him to China in an adventurous surreal journey.

"Gioconda threw open her window.

This poor farmer's daughter

done up as the Virgin Mary

chucked her gilded frame

and, grabbing hold of the rope, pulled herself up..."

The last part of the text is set in Shangai. The places are sketchily described implying class conflicts. After SI YA U's execution by the rulership, she becomes a revolutionary herself and, eventually, is caught and burnt. It is a parable, where the spaces are reflections of ideological aspects.

"Shanghai is a big port,

an excellent port,

It's ships are taller than

horned mandarin mansions."

A more mature example of the Futuristic storytelling long-poems is Why did Benerci killed Himself (1932). Set in India, Benerci is an active member of the independence movement against British rule. When his political cell gets caught, he is dully released and accused of treason by his comrades. The interior where the revolutionaries are raided by the police during their secret meeting is vigorously depicted. Benerci's room embodies his frustration of being left out of the movement while the fusty rooms of British intelligent service agent / former lover and Benerci's tuberculous comrade, Somadeva also indicate their desolation. As, later on, Benerci heroically rejoins the movement in prison the penitentiary surprisingly mirrors his enthusiasm just like the public squares denote the thrill of demonstrations. The exteriors and public spaces are more vivid and incorporate the energy of daily life and political struggle.

Hikmet's early epics contain a political universe of symbols and mainly create a non-personal and abstract environment without detailed descriptions or personalized features yet mirroring the general mood of the characters. Their physicality is a passage to the comprehensible as a symbolic narrative pattern. It corresponds to Paul Ricoeur's concept of intelligibility as an act of configuration, which can be defined as the physical qualities of narrated space about how the spatiality effect crystallizes. This aspect of configuration means the attempt to clarify the inextricable, based on narrative plots tying the events. It expresses how we make sense of what's happening and covers the stylistic and formal aspects of narrated spaces and can be seen as a reply to the question of how. The intelligibility aspect is an abstract depiction of a universal geometric form, which also includes the spatial arrangement of textual elements of composition. For Hikmet, the abstract physical surroundings of his early career merge into the composition of the text making sense of what's happening through their abstractness and connotations.

\section{Emplotment: Space as the Container of the Plot}

In the 1930's, in an artistic environment of nationalism and search for cultural identity, Hikmet turned towards a more communicative approach. Society's historical and cultural identity came into his view and his language has softened to comprise the individual experiences with an ideological load. His poetry after the mid-1930s has become a combination of the lyrical expression of the self and political functionalism. Both inclinations paved the way for an extensive narration with a descriptive edge. Especially in his epic poems he applied new strategies of spatial narration.

\subsection{Concrete Space of Action}

The Saga of Sheikh Bedreddin retells the story of a historical rebellion. Sheikh Bedreddin was an influential mystic, scholar, and rebel. He is well-known for his role in a 1416 revolt against the Ottoman Empire, in which he and his disciples posed a serious challenge to the authority thanks to the popularity of his egalitarian ideology.

This poem marks a crucial change regarding his understanding of space. Space becomes the container of the plot, while the literary emplotment functions through the narrative spaces. Many parts of the epic contain theatrical action in a certain place. Throughout the text, Hikmet is guided through the crucial locations of the revolt by an imaginary guide. The lake at the castle sets the tone, where Bedreddin gives the decision to start the revolt.

"The blacksmith's anvil is a broken heart

The children go hungry

The women's breasts are like dried fish

And the young men don't sing."

Whereas the depiction of İznik city still lacks real-life details, he creates concrete environments and provides us with descriptions to support the main emotion as an impression.

"A barefoot woman is crying on the shore.

And in the lake

an empty fishing boat has broken loose, 
floating on the water

like a dead bird"

The scene, where the poet meets the Sheik himself on a ship, generates an aura of the ship with an impressionist tone:

"On a sea one night a sailboat

alone with the stars.

The stars without number

The sails down.

the water dark

and flat as far as the eye could see"

Depicting the scenes of the preparation of battle, he gives a lyrical description of the earth used as an allegory:

"It was hot.

Hot.

The heat was a dull knife dripping

blood.

It was hot

The clouds were full

the clouds were about to burst.

Motionless, he looked: like two eagles, his eyes dived down from the rocks

into the plain.

There the softest, hardest

most generous, thriftiest

most loving

biggest

most beautiful woman

EARTH

was about

to give birth"

The last part of Saga creates a vivid image of a marketplace, a place that holds the story itself and communicates with the reader.

"The rain hisses, like words of betrayal

whispered in fear

(...) In Serrai's market place

across from the coppersmith

Bedreddin hangs from a tree

The market place is mute

Serrai is blind.

Doomed to the grief of not seeing or speaking

Serrai's market place buries its face in its hands"

Allegorical spatial descriptions are still common but descriptions made of impressions are predominant. The Epic of Sheik Bedreddin presents many spaces as the container of the plot, in other words as a stage surrounding the action.

\subsection{Spaces of Epiphany}

Silent and underprivileged masses, omitted in history works reserved for "great men", were understandably cherished by Hikmet as the real and unacknowledged agents of historical change. Another major project, begun in 1939, was The Epic of War of Independence, narrated, again, from the perspective of numerous men and women who participated in the Turkish independence war from 1919 to 1923 . The individual stories were dispersed within a broader narrative on the actual course of the war.

Comprised of separate sections, each part tells a story of an individual at an important moment of the War of Independence. The first part, the Story of Black Snake, contains a fainthearted young man's turning point to become a legendary soldier. The story is interwoven with a thoroughly described topography of the battlefield. Observing how a snake is hit by fire, the main character realizes that there is no point in hiding and springs into action. The place becomes the carrier of the epiphany.

Because he had never been taught to think.

He lived like a field mouse,

scared as a field mouse.

(...)

He was lying under the rosebush, flat on his belly,

when behind a white rock a black snake raised his head

skin all spangled,

eyes fire-red,

tongue forked.

Suddenly a bullet

tore off its head.

Kerim The Hunchback tells the story of a young messenger, who has become part of the resistance when he was a child while stealing guns from the occupation forces. Their storehouse he used to play around is the place where the character transforms into a young patriot. Moreover, the dramatically depicted forest scene leads him to his fate, where his horse is scared of fire and drags him for hours, which, eventually causes his severe injuries and his hunchback.

Ismail from Arhaveli is a member of the crew of a small craft carrying a machine gun to the front. When they are caught by a British warship, he jumps into a rowing boat to deliver the weapons they were trusted. Despite his skills as a sailor, his luck doesn't go well and he never reaches the land. The rowing boat alone in the sea is the central element of the plot revolving around the patriot's psychology.

The fourth part opens with a scene in a coffeehouse where a teacher decides to participate the army. Another moment of important decision is sealed within the strong presence of the environment:

"I am writing this letter to you at the Kuyulu Coffeeshop The gramophone plays the same Anatolian tunes all the time

with its mouth resembling a trumpet flower"

In another chapter, an Ottoman soldier, Hamdi from Manastır, reports the story of the occupation of Istanbul in 1920, the following raids and, shootouts in his telegraphs to Ankara, the center of the resistance forces. Each telegraph gives a detailed account of the raid of another police station 
conveying the mood they are in.

The story of Kartallı Kazım, a sniper, who ambushes a traitor on a moonlit night to shot him down is a highly cinematographic tale. He follows his target until the seaside and took a few more shots only to kill him with the blade in the end. The chase scene from the forest into the sea is vigorously described, while the poetic punchline comes in the shape of a spatial connotation.

"But after all

the guy was on his horse sleeping.

What I mean is, even in those days, to kill even a man like this

the only possible way not feel sorrow

years later

when you look at the moonlight

is either you have heart of stone

or you have a terrific honest heart"

The Epic of Independence War depicts many stories around important decisions and epiphany moments by individuals, while the spaces set the emotional mood, and, thus, become nested in those moments.

Human Landscapes from My Country, his poetic novel written in the 1940s in prison, demonstrates that he mastered the poetic narration and cinematographic techniques. The poetic prose of nearly twenty thousand lines contains various spatial frames to demonstrate the poverty and injustice in the society through individualistic story arcs. $^{2}$

\subsection{Poems from the Prison}

As Nâzım Hikmet has spent almost thirteen years in prison, the depiction of prison environments is all but expected. In a famous poem, Today is Sunday, the prison courtyard's corporal portrayal is eye-catching. The permission to go out to the prison yard after a long solitary lockdown brings him to a point of tragic acceptance of sensual joy. The picturesque depiction of his body leaning against the wall acts as the main generator of the poetic message and the emphasis of the body's sensual surroundings puts the poem on a special spot in terms of his use of space.

"Today is Sunday.

For the first time they took me out into the sun today.

And for the first time in my life I was aghast

that the sky is so far away

and so blue

and so vast

I stood there without a motion.

Then I sat on the ground with respectful devotion

leaning against the white wall.

Who cares about the waves with which I yearn to roll

2 Human Landscapes needs another categorization for it is a five volumes long poetic novel.
Or about strife or freedom or my wife right now. / The soil, the sun and me...

I feel joyful and how."

During his time in prison, there were certain times he was allowed to manufacture fabric or teach creative writing or painting to other prisoners. His poem Letters from Çankırı Prison written in 1940 makes another sketch of the prison yard in a day when his wife was allowed to visit him. Certain details of the yard are given, such as the size, the wall texture and the fountain in the middle, but space is forged around the rare moments with his wife, which contrasts the suffocating atmosphere of the rest of the prison and the rest of times: Prison yard as a space-time of happiness inside the prison walls.

Nâzım Hikmet met a young İbrahim Balaban in prison and gave him painting lessons, who later became a Turkish painting great. Hikmet wrote many poems on his paintings including Balaban's Prison Door Painting (1945), where he re-depicts the crowd in front of the prison gate in detail. Six women "with patient feet and grief-struck hands", eight children, "too young to even smile", a guard "neither friend nor foe", a mule, which "looks about to cry", a dog ("yellow, with a black nose" and "straw baskets of green peppers and onions". The poem's ending visually emphasizes his distance to his wife and the contrast of inside and outside:

"Six women wait outside the iron gate

and inside -well, there are five hundred men;

you aren't one of the six women,

but I am one of the five hundred men."

In 1949, an international committee, including Picasso, Sartre, and Paul Robeson, was formed in Paris to campaign for Hikmet's release, and in 1950, he was awarded the World Peace Prize. The same year, he went on an eighteen-day hunger strike despite a heart attack, and, eventually, he was released in a general amnesty. Within a year, his persecution resumed full force and his four-part poem After Being Released illustrates the difficulties of that time in Istanbul before he escaped to the Soviet Union and how it is strange to be at home with his pregnant new wife after years in prison. Their house might offer the pleasant homey feeling he craved for so long but it is not an entirely safe place:

"You are safe till night.

Because it's the custom:

the police don't raid houses in broad daylight."

(...)

All of a sudden it's night

The evening walk is over.

A police jeep turned into your street

your wife whispered:

'to our house?"”

Hikmet's spaces between the 1930s and early 1950s predominantly contribute to the plot by marking the locations with crucial decisions, actions, and feelings. It 
can be said, those poems can be associated with Paul Ricoeur's concept of emplotment of configuring a text or a building, or, in this context a narrated space. [19] Emplotment defines how a narrated space contains the plot. It encompasses the content of fiction and the architectural functions and can be seen as the answer to what is happening in which space. Hikmet's uses the spaces like the skin of the storylines indirectly reproducing the emotional impact through the spatial environment. His communicative and storytelling poetry gains an affective edge thanks to the architectural atmospheres and his narrated spaces acquire a predominant emplotment aspect in this period.

\section{Context: The Significance of the Place}

Hikmet ultimately left Turkey in 1951 to spend the rest of his life in the Soviet Union, where he was welcomed as a cultural attaché. It is no surprise that his poetry in this period obtained a special agenda related to places, cities, and geography. The emphasis on the spatial images around the idea of homesickness opened up various strategies and resulted in references to real-life places more often than not. Looking at the cities and places, one comes across a variety of them from Havana Libere Hotel to Uzbeki Gardens in Cairo. All those locations act as the landmarks of his complicated situation.

\subsection{The Pre-Existing Image of the Place}

Dealing with real-life places brings forth the pre-existing image of a place in the collective consciousness within a particular context. Hikmet uses real-life places not only as actual surroundings but as signs with existing connotations. Many of his places in this period have an additional layer of what they represent.

Hikmet depicts the "heavenly mansion" of ÇI ÇUN TIN in the city of Kun-Min in China, where the tyrant S1-Si once enjoyed the spring, and where Hikmet watched the boats passing with people inside singing "Sunrise in the East" after the revolution in China. In My First Rome Evening, Hikmet recounts urban scenes under the rain on his way to a meeting such as fountains, red ants, sycamore trees, shiny windows, and smoking women under the rain. Or, in one untitled poem [I have bathed in all fountains], Hikmet gives another visitor's account of Rome emphasizing its multifaceted character in a surrealist fashion: "I rode all the horses of the city of Rome the golden horses bronze horses on the pillion of the street kids and spartacus and been harness to coaches along with the tourists". Yet, the breathtaking Rome urbanscapes are inconsequential in comparison to political salvation.

His travel poems present a rich variety of landscapes and cityscapes implicitly linked to the political changes after the Second World War. They give him the necessary material for ideological observation. One of his several travel poems, Poland Letter, includes not only notes of romanticized ideas about socialism but also his family history, which goes back to Poland. In his Hungary Notes, he mentions his visit to a well-known orphanage in the countryside to focus on the social changes brought by the regime. In Passing Through Switzerland, he portrays the Swiss landscape to imply his slightly critical views on the countries with questionable wealth in his eyes. ${ }^{3}$

\subsection{Landscapes and Cityscapes on a Political Background}

The Lyrical Interview about Romania includes passages directly outlining Romanian houses. An active advocate of socialism and a celebrated cultural attaché of the Soviet Union, he started being critical towards Stalin's reign around his dead in 1957, although his belief in utopic socialism remained untouched. His commentary on Romanian architecture takes a more sociological turn by pointing out that the new houses are occupied by regular people from the working-class and he tries to underline the labor behind the construction mobilization.
"I saw new houses
they were rainbows
and water at dawn
I came across them in Brasov
along with mountains
And at Black Sea,
from Mamaia to Mangalia
the houses were
the joy of fountains.
The cosiness of ironed, clean laundry
Thank you architects
I mean, the ones after 1957"

In his poem, In the Astoria Restaurant in Berlin, Hikmet recalls his impressions about a waitress, whom he has never actually spoken. Through an unexpected jump, the second part of the poem is written from the waitress' perspective about him, as an old stranger who has regularly visited the restaurant. The restaurant is the container of the impressions of two strangers on social background, who are curious and compassionate towards each other without knowing each other. In his poem, A City, Hikmet depicts Leipzig from a pedestrian's eye without any specific characteristics of the city. It is simply called a city, and only the ending note denotes that it is written in Leipzig in 1961. He discusses how a city in the visitor's eye might look like to be made of so many different things, which

3 There is another group of poems, mainly written in that period, which in an equilibrium of emplotment, intelligibility and context qualities work as total metaphors, such as Straw Blond. However, they deserve another focus on the idea of metaphor and will be brought up in another article. 
doesn't resemble each other. Yet, all the people ironically echo each other as a result of the same complexity of their characters. This contrast between the generic yet different elements of a city and the similar yet complex human beings is the main idea of the poem.

In Certain Moments, he speaks of the Three Lilies Hotel in Bohemia, where he and also Goethe, according to Czech poet Nezval, has stayed and depicts the thermal baths at the beginning of the poem. Then, Hikmet changes the course of the poem towards the German Occupation of the city of Frantişkovi Lazni, when the tanks "shook the building so hard / a table fell over upstairs".

"The sky swells with hot clouds.

In the Turkish bath, light seeps through the steamed-up window,

the smell of moist flesh mingling with the scent of red roses.

Water flows freely here, curing heart pains impotence, and trees branch out as far as you can see.

It seems that if you stepped down hard enough, a spring would bubble up, rich in sulfur and calcium, or a thick beech tree rise all green and white."

Paris is another frequent location of his visits, as a group of Turkish intellectuals, including his friend and outstanding painter Abidin Dino, have been living there. Paris becomes a well-integrated background for his love affair in his Before The Time Runs Out My Rose. He longs for his lover in midst of protests in Paris in 1958 as the cityscape interlocks with the lovers' bodies.

"Before the time runs out, my rose, before Paris is burned down and destroyed, before the time runs out, my rose, and my heart is still on its branch, I, one night, one of these May nights, holding you against the wall in Quai Voltaire, must kiss you on the lips then turning our faces toward Notre Dame (...)

Up there stone houses

without ledges or recesses

stuck together and their walls are all moonlight and their windows straight up are sleeping standing up and on the shore across the Louvre bathed in floodlights our crystal palace illuminated for us."

\subsection{Places of Longing and the Past}

Some of his Hikmet's poems explicitly contain sceneries representing an emotion such as longing, nostalgia, or fear of death due to their context. Expectedly, longing is a central theme of his years in exile and it is principally expressed through the similarity and distance of a place to Istanbul. His short poem Blue Harbour embodies his despair reiterating his geographical distance to Turkey.

"I'm too tired, do not wait for me captain.

Let someone else write the journal.

It's a blue harbor with plane tree and a dome.

You cannot make me land on that harbor.

I'm too tired, do not wait for me captain."

Another notable theme is the flooding of memories in a place. For Hikmet, certain spaces are first and foremost the reminders of the memories. The Three Stork Restaurant in Prague, where Hikmet used to meet his secret lover, who passed at an early age. The restaurant is the container of the memories as Hikmet dreamily remembers her. In his Tanganika Interview, he mentions the Ozbekia Gardens in Cairo. The lines "I found the park bench we sat / they didn't fix it's leg" turns a physical detail into a token of the temporality of place. Through the remembrance of specific physical traits, Hikmet implies how stunning his previous visit with Vera Tulyakova, his wife, was.

Memories also remind the passing of time and the inevitability of death as it can be seen in his poem The Christmas Tree, which opens and closes with an architectural scene. Hikmet creates a contrast between the dark gothic towers and the red shiny balls hung from a Christmas tree so that he relates his fear of death with his passionate love.

"a Christmas tree with tinsels

Near to the smokey sea

in between the dark gothic towers and crests of the Teutonic knights

and surrounded by factory chimneys

(...) you are in a red glass ball

your hair straw-blond your eye-brows blue

I put you in there".

In one of his popular poems, Last Will and Testament, he describes his ideal graveyard. Mixed with the modesty and yearning to his homeland, he idealizes a humble graveyard amongst the poor and downtrodden, yet he doesn't waive from his dream of freedom as his image of the grave is set in an ideal future, when "fields held in common, water in canals". His depiction of the place recreates his yearning and ideology, and, thus, integrates into the plain and naive language in the poem.

"The worker Osman whom Hassan Bey ordered shot

can lie on one side of me, and on the other side

the martyr Aysha, who gave birth in the rye

and ide inside of forty days

(...) comrades, if I die before that day, I mean

- and it's looking more and more likely-

bury me in a village cemetery in Anatolia

and if there's one handy,

a plane tree could stand at my head

I wouldn't need a stone or anything"

It can be noticed that the real-life places play an 
important part in his last period. The poem From Sofia includes a recollection of childhood memories in Istanbul. In Bor Hotel, a hotel room in Bulgaria solely exists as a faraway location. In the poem Baku At Night, his melancholy is integrated into the scenery by comparing Baku's evening lights and sounds to those of Bosphorus. The spaces in those poems not only form a space in imagination but also connect the poem to the surroundings of the described space. A narrated real-life space exists with the already given connections to the setting of architectural entities and cityscapes. According to Paul Ricoeur, the final aspect of the configuration act is the context for a space (or interdisciplinarity for a text).[19] and it what Hikmet uses in his late years. The context is the relationship of space with all other spaces. It designates the relational singularity of a space, which extricates its sui generis qualities and differences from the rest. By referencing and using real-life spaces in his poetry, Hikmet certainly exploits the rich reference world of the context of his spaces while creating places with an intrinsic link to his persona.

\section{Discussion and Conclusions}

In general, all narrated spaces have an equivalent of geometric description, an immediate tie to the plot, and a particularity on the level of the narrative universe. In other words, every narrative space holds a configuration aspect of intelligibility, emplotment, and context. The more generic spaces present themselves as self-reliant objects, slightly detached from the plot and, thus carrying denotations. The experience emerging from the bare physical qualities correlates to an architectural and literary stylistic effect -intelligibility as Paul Ricoeur would call it.

On the other hand, Hikmet's concrete descriptions lead to a different type of attention to what rather than how. The concreteness sharpens the individuality of a place to constitute a symbiosis relationship with the plot as the emplotment aspect plays a central role for many of Hikmet's spaces.

Finally, each architectural narrative artifact comes within a context of links to the rest of the world. Not only the space itself, but its relational meaning in the universe of the narrative also establishes a feeling. Hikmet's real-life spaces strikingly employ contextual properties.

Hikmet used all three configurative aspects of a narrative space with a richness of poetic techniques. An analysis of his work also shows that all configurative planes can easily be folded into each other. They all play roles in the composition of the text, just like they do in architecture. It can be concluded that each configurational aspect can be used as an artistic tool. However, the interpretation of Hikmet's narrative spaces demonstrates each aspect has its own way to make an artistic effect. The three-dimensional qualities create a direct feeling that can operate as an impression or symbol, the content of spaces can mold the action for a reflexive impact, and the contextual qualities can reframe the signified meaning.

Configuring the text, or the narrated spaces in this context, as the main realm of operation, which connects Hikmet's own perception of the world to the mind of the reader. Hikmet's poetry has always been fed by real life, autobiographical or social, and has always tried to reach out to the people with a functional agenda. It is that connection, which brings Hikmet's understanding close to Ricoeur's methods. Ricoeur's parallel theory of literature and architecture allows to combine a spatial form of textual composition with the three-dimensional qualities of narrated spaces in a threefold matrix of life, production, and interpretation working on both literary and architectural levels. His conception provides a terminology, which can freely move between the realms of architecture and literature so that it unfolds a productive section to process the narrated spaces. [20] Prefiguration is the condition of narration as a discourse comprised of the pre-existing experience and expectations of stories we bring with us when reading. According to his architectural model, prefiguration is related to the act of dwelling. In that regard, Hikmet's urge to be nourished from the real-life finds an echo in Ricoeur's parallel theories. Refiguration, the final main act of the narrative, is the reading and interpretation by the reader, as they complete a story in restoring it to the real world of action. The reader, "this forgotten protagonist of structuralism", is the enclosure of the text. [19] In the architectural sphere, the refiguration moment would entail a thoughtful dwelling, the way space is used, experienced, and rearranged in the realm of inhibiting.

"I placed under the very ancient title of mimesis - that is, of recreation, of creative representation - while coming from the stage of 'prefiguration' in which the narrative is tied up in everyday life, in conversation, still without detaching itself to produce literary forms. I will pass next onto the stage of a truly built time, of a recounted time, which will be the second logical step: 'configuration.' And I will end with what I called, in the context of reading and rereading, "refiguration." [19]

Ricoeur's view incorporates two aspects, which bring forth a more inclusive edge regarding structuralist analysis of narrated spaces. Firstly, what is believable as a story should have a ground on the prefigured worlds of authors and readers. And secondly, the narrative is restored to the real world through the refiguration, completing not only a phenomenological step but also places the text on the social level and completing the cycle. In Hikmet's eyes, neither a poem without the reader nor a narrated space, which does not trigger the imagination about the inhibiting, would carry too much importance. Hikmet's narrative spaces shows us how he brings the need of writing and the goal of writing together. His configured spaces, inspired by life itself are the sources of the emotional impact in reader's 
mind.

Remembering Vitruvius' canonical categorization of the architectural object as firmitas, utilitas and venustas (i.e., structural stability, appropriate spatial accommodation, and attractive appearance), it can be said that Ricoeur's understanding and Hikmet's narrative spaces offer a new perspective on how the functional needs (prefiguration) might affect the experience and emotional impact (refiguration). In Hikmet's poetry, the configurative aspects of narrative spaces are the results of the needs and the sources of aesthetic experience. They demonstrate that aesthetic appraisal is closely linked to what and in what context, too, rather than only to a bare how.

\section{REFERENCES}

[1] Baumgarten, A. G., Reflections on Poetry: Alexander Gottlieb Baumgarten's Meditationes, University of California Press, 1954 [1735]

[2] Wölfflin, H., "Prolegomena to a Psychology of Architecture" KeepAhead Press Architectural Theory, 2016 [1886]

[3] Husserl, E., "Ding und Raum / Vorlesungen 1907 / Text nach Husserliana Band XVI", Hahnengress K-H. and Rapic (eds.), S., Felix Meiner Verlag, Hamburg, 1991 [1907],

[4] Merleau-Ponty, M., "Phenomenology of Perception", Routledge\&Kegan Paul Ltd., Ebby Vale, 1996 [1962]

[5] Pallasmaa, J., "The Eyes of the Skin: Architecture and the Senses", Wiley, 1996

[6] Robinson S., Pallasma J. (eds.), "Mind in Architecture: Neuroscience, Embodiment, and the Future of Design", The MIT Press, 2015

[7] Barthes R., "Semiology and Urbanism", in Joan Ockman (ed.), Architecture Culture 1943-1968, A Documentary Anthology, Rizzoli International Publications, Inc., New York, 1993

[8] Umberto Eco, "A Componential Analysis of the Architectural Sign /Column/”, Semiotica 5:2, 1972

[9] Lotman, J. M., "The Structure of the Artistic Text", Ann Arbor: University of Michigan Press, 1977 [1970]

[10] Joseph Frank, "The Idea of Spatial Form, Rutgers University Press", New Brunswick and London, 1991

[11] Zoran, G., "Towards a Theory of Space in Narrative", Poetics Today 5:2, 1984

[12] Dennerlein, K., "Narratologie des Raumes", de Gruyter. 2009

[13] Hamon P., "Expositions, Literature and Architecture in Nineteenth-Century France", University of California Press, 1992

[14] Ricoeur, P. "Intellectual autobiography", in The Philosophy of Paul Ricoeur, (ed.) Hahn, L. E., Chicago and La Salle: Open Court, 1995

[15] Ricoeur, P, "Architecture and Narrativity", Études Ricœuriennes / Ricœur Studies, 7:2, 2016 [1994]

[16] Terzoglou, N. I., "Architecture as Meaningful Language: Space, Place and Narrativity", Linguistics and Literature Studies, 6:3, 2018

[17] Hikmet, N., "Poems of Nâzım Hikmet", trans. by Blasing R., Konuk M., Karen and Michael Braziller Books, 2002

[18] Hikmet, N., "Beyond the Walls", trans. by McKane R., Christie R., Halman T.S., Carcanet Press Ltd., 2007

[19] Ricoeur, P, "Architecture and Narrativity", Études Ricœuriennes / Ricœur Studies, 7:2, 2016 [1994]

[20] Ricoeur, P., "Time and Narrative", University of Chicago Press, 1983 